\title{
Measuring Performance in Rail Freight Transportation Companies
}

\author{
Guilherme F. Frederico ${ }^{1} \&$ Vagner Cavenaghi ${ }^{2}$ \\ ${ }^{1}$ School of Management, Federal University of Paraná - UFPR, Curitiba, Brazil \\ ${ }^{2}$ Industrial Engineering Department, São Paulo State University - UNESP, Guaratinguetá, SP, Brazil \\ Correspondence: Prefeito Lothario Meissner, 632, 2o.floor, Jardim Botânico, School of Management, Federal \\ University of Paraná - UFPR, Curitiba, PR., Postal Code: 80210-170, Brazil.
}

Received: September 5, 2017

Accepted: September 26, 2017 Online Published: October 13, 2017

doi:10.5539/ibr.v10n11p117

URL: https://doi.org/10.5539/ibr.v10n11p117

\begin{abstract}
Performance Measurement Systems - PMSs has become relevant for Organizations in the last years taking into consideration the broad approach and the strategic link which the current performance measurement is focused on. Brazilian railroad transportation has poor performance when compared with other similar countries. The rail transportation production has $25 \%$ of participation within total transportation matrix. Besides infrastructure aspects, management is the key for the improvement of this performance. A Performance Measurement System PMS framework using Balanced Scorecard - BSC structure is proposed aiming to allow a more comprehensive and strategic performance measurement in railroad companies. A systematic approach was used for the literature review. Due to the lack in the literature related to the purpose of this paper a long period was considered for the search of references linked to performance measurement for railroads. Aiming to elaborate a PMS framework for railroad companies a case study method was applied in a large Brazilian railroad company. Semi-structured interviews and documental data collection were used in order to get evidences related to the processes, environment, customers and strategic objectives as perspectives needed to elaborate a PMS based on Balanced Scorecard. This case study applied in a large freight railroad company in Brazil allowed to understand typical strategic objectives as well as processes, customer's requirements and environment related to this kind of business. Balanced Scorecard was suitable to the performance measurement needs of the railroad company operation. It can measure operations performance comprehensively and strategically in an effective way. This study brings up important contribution in terms of PMS literature and it can be used as a reference guide for future researches focused on this field. Also it can be worth for practitioners who desire implement PMS in Organizations, not limited for railroad companies, but also for other kind of operations. This framework proposed is unique taking into consideration that there is no comprehensive PMS for a railroad companies using Balanced Scorecard structure. This same structure can be applied in more field researches seeking better understandings about performance measurement in freight railroad companies. Some research questions in order to solve future issues related to this study are proposed at the end of this paper.
\end{abstract}

Keywords: performance measurement, balanced scorecard, rail transportation, case study

\section{Introduction}

According to the Ministry of Transportation (2016), the Brazilian railroad system has 28,190 Km, present in the south, southeast and northeast, also taking part of the central west and north of the country. This is the biggest railway system in the Latin America. However when compared with USA system which has about 210,000 Km (Association of American Railroads, 2016), it is possible to verify the lack of railroad system development.

In 2014 it was transported 140.4 Million tons in the Brazilian system. More than 35\% of freights exported from Brazil are transported by railroad to the Brazilian ports (Association of Brazilian Railroad Companies, 2016).

For the Ministry of Transportation (2012), as presented in Table 1, in countries with large territorial dimensions, such as Brazil, the share of railroad modal is more than $40 \%$ within the matrix. Brazil has only $25 \%$ of share in terms of railroad transportation 
Table 1. Transportation Modes Share per Countries

\begin{tabular}{cccc}
\hline Countries & Road & Railways & $\begin{array}{c}\text { Waterways and } \\
\text { Others }\end{array}$ \\
\hline Russia & $8 \%$ & $81 \%$ & $11 \%$ \\
United States & $32 \%$ & $43 \%$ & $25 \%$ \\
Canada & $43 \%$ & $46 \%$ & $11 \%$ \\
Austrália & $53 \%$ & $43 \%$ & $4 \%$ \\
Brazil & $58 \%$ & $25 \%$ & $17 \%$ \\
China & $37 \%$ & $50 \%$ & $13 \%$ \\
\hline
\end{tabular}

According to Towson University (2016) the freight rail achieved in United States was about 2,847 billion of tku (tonne useful $\mathrm{x}$ kilometer) in 2015, followed by China with about 2,209 billion of tku and Russia with 2,075 billion of tku. This means that the productivity of US system is almost 9 times higher than Brazil that achieved 332 billion of tku (Association of Brazilian Railroad Companies, 2016)

According to data presented Brazil need to improve significantly its railroad transportation in order to achieve a more balanced transportation matrix. This poor performance impacts directly the country in the world trade, mainly because the country has a large dependency in commodities production which most of needs to be transported by train. It is clear that the infrastructure issues have a huge impact on this poor performance but management is also the key.

Thus, take this into consideration, an effective PMS for railroad transportation can support management decisions regarding operations matters. In this way, this research aims to present a PMS framework to be used by railroad companies. Also, this research brings contribution for the theory in terms of PMS applications.

This paper is structured as follows: next section will bring the literature review about performance measurement and in specific balanced scorecard. After that the research method will be presented and justified. In the sequence, empirical research with data collection and findings will be present. Lastly, conclusions and final remarks close this article.

\section{Literature Review}

\subsection{Performance Measurement}

Performance measurement has been one of the important topics for researches in the last two decades since them the broad perspective was defended by Eccles. For Eccles (1991), there was a need to stop of considering only financial indices as the basis for the performance measurement. Abroader range of indicators became a necessity faced with the new competitive environment in 1990's.

Lebas (1995) consider that performance is defined as the potential for future success in the implementation of actions required to achieve the targets and objectives.

Neely, Gregory \& Platts (1995) defines performance measurement as being "the process of quantification of the action, where measurement is the process of quantification and the action is what leads to the performance". For Neely, Gregory and Platts (1995) a system of measurement of performance must contain individual measures interrelated one each other pertaining to certain environment. According to these authors, when carrying through a project of a PMS some questions must be done:

Which measurements of performance are used?

Why are they being used?

How much will they cost?

What benefits can they offer?

Lebas (1995) states that the performance measurement and the performance management are not separated. According to author there is an interactive process between these two issues. PMS is the information system that is at the heart of the performance management process (Bititci, Carrie \& Mcdevitt, 1997).

Thus, it is necessary in the performance measurement an approach beyond the financial focus. The qualitative factors of process and the stakeholders' satisfaction in the organization, like customers, employees and others are included in the news models of performance management, being linked to issues such as market, news technologies and economy, with necessarily, a connection with the strategic scope modern organizations. 
The performance measurement must be part of the process control involving the strategic, tactical and operational levels, assessing through of a continual way the planning and the actions implemented under others views beyond the financial.

PMSs offer, through a set of information, a support to the process of performance management, which has a broader approach. In de veloping of a PMS it is important to understand the reasons, costs and utilizations of measures. It doesn't make sense to have many measures without link with the corporate and operations strategy. Also, it cannot require huge effort to obtain measures, costing lots of money and taking so much time from people who are responsible for the performance measurement.

PMSs should have attention in terms of its evolution and stages of development. Authors as Van Aken et.al. (2005) and Wettstein \& Kueng (2002), have proposed on the literature maturity framework in order to assess the evolutions of PMSs.

Newer PMSs consider this balanced structure for the performance measurement process. Some frameworks have been proposed in the literature as Performance Prism (Neely, Adams \& Crowe, 2001) and Balanced Scorecard (Kaplan \& Norton, 1996).

Some authors have strongly criticized the use of BSC as Voepel, Leibold \& Eckhoff (2006). However this PMS has successfully been used for many world class companies in the world. Balanced Scorecard is certainly one of the most used PMS by the companies in the current context.

\subsection{The Balanced Scorecard}

The Balanced Scorecard was developed in 1990 from a work group from Nolan Norton Institute, which assisted the KPMG in research and development of new management models. The objective of the group was to create a model of measuring performance in organizations of the future, since the existing models until then were already considered obsolete. The leader of the study was David Norton, CEO from the Nolan Norton Institute at that time, being assisted by Robert Kaplan, acting as academic consultant. During the year of 1990, representatives of twelve companies from the sectors of manufacturing, services, heavy industry and high technology were brought together to develop the new model of performance evaluation.

According to Kaplan \& Norton (1996), the organizations were contesting in complex environments where the understanding of their goals and methods to reach them, are vital aspects for their own survival. The authors say many service organizations, mainly transports, communications, economy and utilities exist over decades in a noncompetitive environment. However, the age of information has requested new potentialities for the competitive success.

For Kaplan \& Norton (1996), the Balanced Scorecard measures the operational performance through 4 perspectives: financial, customers, processes and learning and growth.

Perspective of learning and growth is the basis for the processes. It is related to how company will support changes and improvement in order to achieve the corporate mission and vision. Perspective of processes is related to initiatives with regards to achieve excellence in business processes aiming to satisfy customers and consequently shareholders. Perspective of customers is related to initiatives about customer relationship and satisfaction. Lastly, financial perspective is the result from other three perspectives with regards financial results and satisfaction of shareholders.

Niven (2002) defines Balanced Scorecard as a careful set of measurements derived from the strategy of the organization. According to the author, the Balanced Scorecard represents a tool which the leaders can use when communicating with employees and external interested parties the results and the direction of performance through where the organization will reach its strategical mission and its objectives.

For Niven (2002), the BSC is a model that includes three functions:

- System of Measures;

- System of strategic management; and

- Tool of Communication.

According to Frost (2000), the BSC is a good example of system of performance measurement model that shows a vision of news perspectives, beyond of financial.

The objectives and measures of performance for the Balanced Scorecard are more than a collection of financial and non-financial measurements of performance. They are derived from of a top-down process application of the united business' mission and strategy (Kaplan \& Norton, 1996) 
According to Kaplan \& Norton (2001), although each organization can achieve the alignment and strategical focus in many ways, in many places and in many sequences, each one use a common set of five principles as follows:

1) Translate the strategy to operational terms

2) Align the organization to the strategy

3) Make strategy everyone's Job

4) Make strategy a continual process

5) Mobilize change through executive leadership

In the first principle, the strategy must be transmitted following a logic architect of a strategic map and a group of balanced indicators, looking for specifying the details, the critical elements for strategies growth. This happens to create a common and understandable reference point through all the units in the business organization, also all their employees.

For Kaplan \& Norton (2001) organizations are complex, building many times their numerous departments, business unities, specializes departments, having their own knowledge and culture.

For these authors, the functional divisions come and become the biggest obstacles for the implementation of the strategy that many organizations have great difficulties to communicate and coordinate these divisions. For the organizational development be more than the total amount of sum parts, individual strategies must be joined and integrated. By this idea it is presented the second principle of the organization focused on strategy.

The third principle contemplates the realization of the strategy for a daily work of all in between the organization. This principle requires that all employees understand the strategy and lead on a daily basis into the business to add for the implementation of its success. The executives can begin this process using the BSC to communicate and educate the organization about the strategy to be implemented (Kaplan \& Norton, 2001)

On the forth principle, Kaplan \& Norton (2001) establishes that the strategy must be accomplished by a continuum process, they say, many organizations build their management process through budgets and operational plans. According to them, the organizations introduce by BSC a double continuum process to manage the strategy. The process integrates the management tactics with management strategies, using three important processes which are the strategy linked to the budget process, the strategy review process, the learning and the strategy adaptation.

For Kaplan \& Norton (2001), the four first principles focus on BSC as tool, structure and process to support them. For these authors, the strategy implementation requires changes for each part of the organization. Moreover, it also requires a team to coordinate these changes. For them the BSC program begins on the mobilization and the creation of a moment for the process to be released. Right after, the focus turns to be on the governance to implement a new development model. Finally and gradually, a new management system evolves into a system of strategic management which institutionalizes a new culture, values and processes into a new system to manage it. This can support strongly not only the performance measurement but also the performance management.

Then the BSC is more than just a PMS. It is also an instrument of strategic management, aiding in the clarifying and transmission of vision, communication and establishment of goals, planning and definition of the objectives and strategic feedback and learning. It allows company measure effective performance aligned with strategic objectives much more than only operational performance.

\subsection{PMS for Rail Companies}

A literature review was carried out in order to identify PMSs for railroad companies. According to Table 2 it is possible to verify that the PMS approaches are more related to benchmarking, efficiency, maintenance and infrastructure and sector analysis. There are no proposals with the objective to measure a railroad company as a whole. These proposals do not present a comprehensive framework in terms of perspective in an integrated structure.

In this way, it is possible to affirm that there is a lack with regards methods and frameworks to measure rail companies. Thus, this study can bring a novel research presenting a valuable framework for both practitioners and researches interested in rail companies' performance measurement. 
Table 2. Performance Measurement Researches for Railways

\begin{tabular}{|c|c|}
\hline $\begin{array}{l}\text { Performance Measurement } \\
\text { for Railways }\end{array}$ & Research Scope \\
\hline $\begin{array}{ll}\text { Jorge-Moreno } & \& \\
\text { Garcia-Gebrian (1999) } & \end{array}$ & $\begin{array}{l}\text { It is related to Performance of European Railway Industry. There is no PMS framework } \\
\text { proposal. It has focus on production efficiency of Railways companies as a whole. }\end{array}$ \\
\hline Walters (1999) & $\begin{array}{l}\text { This research focuses on PMS for Property Management in a Railway Company. PMS } \\
\text { considers only Customer Satisfaction Perspective. }\end{array}$ \\
\hline Lan \& Lin (2006) & $\begin{array}{l}\text { The approach is related to performance measurement in terms of technical efficiency. It is } \\
\text { applied a stochastic method making the comparison of performance of } 39 \text { worldwide } \\
\text { railway systems. }\end{array}$ \\
\hline Sajeev \& Narayan (2008) & $\begin{array}{l}\text { Study has focus on operational efficiency performance. There is no strategic approach and a } \\
\text { PMS framework is not proposed. A DEA (Data Envelopment Analys is) methodology is used } \\
\text { for the research. }\end{array}$ \\
\hline Ahren \& Aditya (2009) & $\begin{array}{l}\text { Two case studies were carried out in order to identify indicators for maintenance (MPIs) and } \\
\text { make a benchmarking between these railway companies. PMS framework with broad } \\
\text { perspectives is not approached. }\end{array}$ \\
\hline $\begin{array}{l}\text { Stenstrom, Parida \& Galar } \\
\text { (2012) }\end{array}$ & $\begin{array}{l}\text { PMS proposed for maintenance and infrastructure perspectives. Consider health, safety, and } \\
\text { environment and maintenance aspects. There is no strategic and broad perspectives neither a } \\
\text { cause-and-effect link between indicators. }\end{array}$ \\
\hline $\begin{array}{l}\text { Mir Ali, Ghaderi \& Rostami } \\
\text { (2013) }\end{array}$ & $\begin{array}{l}\text { There is no PMS proposed based on BSC. It just presents some initiatives that were } \\
\text { implemented since that BSC was implemented at Khorasan Railway Company }\end{array}$ \\
\hline Sharma et.al. (2016) & $\begin{array}{l}\text { Research was focused on measuring performance of Indian Railways in terms of efficiency } \\
\text { of service. It has an operational perspective only using DEA methodology }\end{array}$ \\
\hline Rajeev et.al. (2016) & $\begin{array}{l}\text { Comparative performance between } 16 \text { Indian Railway Zones. There is no focus on PMS for } \\
\text { performance measurement of Rail company itself. }\end{array}$ \\
\hline
\end{tabular}

\section{Research Method}

This research used a qualitative approach taking into consideration that there are not approaches with regards BSC for railroad companies. Also, the objective is to explore a phenomenon which is the application of the BSC for this kind of operations. As the most used method in qualitative approaches is the Case Study.

For Bryman \& Bell (2007), the case study implicates in a detailed an intensive analysis of a simple case or multiple cases. A case study is involved into the complexity and the private nature of the case itself. Voss, Tsikriktsis \& Frohlich (2002) define a case study as a description of a phenomenon, past or present, described from multiple evidences. The case study, according to the authors, may derive from direct observation or systematic interviews, as well as from public or private databases. They affirm that one of the advantages of this method is the possibility of studying the phenomenon in the specific context in which it occurs, allowing the whys and queens to be answered based on a systemic and holistic understanding of the phenomena studied.

The distinguishing feature of the case study lies in its ability to deal with a wide variety of evidence - documents, artefacts, interviews and observations (Yin, 2003). It is common to question the number of firms studied, especially in single case studies, but for Yin (2003) it is only justifiable in situations where the case represents a crucial test of the existing theory; or when the case is a rare or exclusive event or the case serves a revealing purpose. In addition, the single case study may involve only one unit of analysis (holistic).

The research method involved a case study carried out within a Brazilian freight railroad transport operator, with the aim to map overall operations and the its relation with the strategy in order to build the framework to be proposed on this article. This case can be considered as crucial since there are few railroads in the country and there is a strong similarity between the operations

As the collection instruments was used a semi-structure interview using a research protocol. This research protocol was elaborated based on the BSC structure. Documental data was used as well in order to gather more evidences about the research objective.

The steps executed on the research using the case study method were as follows:

1) Constructs for the Research Protocol as basis for interviews and documental data collection

2) Case Study Planning: Definition of unity analysis (areas of railroad company), people to be interviewed definition, sequence of questions and documentation collection

3) Data Collection: Execution of interviews and documentation and data collection (data about processes, railroad company areas, environment, strategic objectives, typical measures, stakeholders, customers' expectations and needs)

4) Data Analysis: Data was analyzed against BSC structure and concept. Data was analyzed in terms of strategic objectives, cause-and-effect between these objectives, processes in the departments or railroad company, environmental and stakeholder analysis, measure needs) 
5) Theoretical Framework: Based on data analysis the theoretical framework was elaborated. It follows the structure of BSC strategic map in terms of measurement perspectives, cause-and-effect link and strategic link.

Figure 1 presents the theoretical framework. It was used as basis for the PMS formulated.



Figure 1. Presentation of the strategic map for BSC model

The theoretical framework present a bottom-up approach, which, from the perspective of learning and growth , keep processes more effective, which guarantee the satisfaction and retention of customers, seeking up achieving the financial objectives of the organization. The BSC as PMS for railroad companies was elaborated based on this theoretical framework. It will be present on the next section containing the performance measures according to each perspective of BSC structure.

\section{BSC for Railroad Companies}

This framework comes from the theoretical framework based on the Strategic Map of the company. The performance measures are divided by four BSC perspectives: learning and growth, processes, customers and financial, as follows in this text. In case of the processes perspective, in this paper will be present only operational processes perspective, due to its greater relevancy for the performance of the operator of freights railroad transportation. On the research measures were also proposed for administrative, commercial, procurement and information management processes.

PMS measures developed for the framework is as follows:

1) The Learning and Growth Perspective's Indicators

- Index of implementation in Information technology

- Index of implementation of training

- Index of retention in formation programs

- Index of employees' satisfaction

- Turn-over of employees

- Frequency tax (work accident)

- Index of occupational health

- Index of absenteeism

2) The Operational Processes Perspective's Indicators

- Locomotives productivity (tku/kgf)

- Wagons productivity (tku/kgf) 
- $\quad$ Rail Productivity (tku/(km.km/h))

- Terminals utilization $(\%)$

- $\quad$ Locomotives availability (\%)

- Wagons availability (\%)

- Terminals availability $(\%)$

- $\quad$ Rail availability (\%)

- Timeline accomplishment of recovery rolling materials projects (\%)

- $\quad$ Timeline accomplishment of construction and recovery of rail projects (\%)

- Locomotives reliability (\%)

- $\quad$ Transit-time of trains (h)

- Cycle time of wagons (h)

- $\quad$ Utilization of the traction capacity (\%)

- Utilization of wagon capacity (\%)

- Index of Accidents (accident/million train x km)

- $\quad$ Loading efficiency $(\%)$

- $\quad$ Unloading efficiency $(\%)$

- Permanence time wagons in terminals (h)

- Waiting time of trucks in transhipment (h)

- $\quad$ Production of transportation efficiency (\%)

- $\quad$ Energy efficiency of transport (1/tkb)

- Accuracy of production monthly planning (\%)

3) The Customer Perspective's Indicators

- Index of accomplishment of contracts (\%)

- Index of customers' satisfaction(\%)

- Index of retention of customers (\%)

- Index of prospection of customers (\%)

- Index of market share in current business (\%)

- $\quad$ Index of entrance in news business (\%)

- $\quad$ Attendance flexibility to additional demand (\%)

- Index of products mix increase (\%)

- Commercial average speed $(\mathrm{km} / \mathrm{h})$

4) The Financial Perspective's Indicators

- $\quad$ Profit per stock $(\$)$

- $\quad$ EBTIDA - Earnings before taxes, interests, depreciation and amortization(\$)

- $\quad$ ROI - Return on investment (\%)

- $\quad$ EVA - Economic value added (\$)

- $\quad$ TSR - Total shareholder return $(\%)$

- Index of reduction of costs $(\%)$

- $\quad$ Flows profitability $(\$ /$ tku $)$

Each measure is linked to a strategic objective. For each measure was also established a formula and frequency of measurement. The Table 3 represents the Framework containing strategic objectives, measures, formula and frequency. For each perspective was developed a table as demonstrated on Table 3. This example is related to Operational Processes Perspective. 
Table 3. BSC framework for Railroad Companies

\begin{tabular}{|c|c|c|c|}
\hline \multicolumn{4}{|c|}{ OPERATIONAL PROCESSES PERSPECTIVE } \\
\hline $\begin{array}{l}\text { STRATEGIC } \\
\text { OBJECTIVE }\end{array}$ & INDICATOR & FORMULA & FREQUENCY \\
\hline \multirow{4}{*}{$\begin{array}{l}\text { Maximize Assets } \\
\text { Productivity }\end{array}$} & $\begin{array}{l}\text { Locomotives Productivity } \\
\text { (tku/kgf) }\end{array}$ & [(tku generated)/(total of Kgf available)] & Monthly \\
\hline & $\begin{array}{l}\text { Wagons Productivity } \\
\text { (tku/vagão) }\end{array}$ & [(tku generated)/(Wagons avalilable)] & Monthly \\
\hline & $\begin{array}{l}\text { Rail Productivity } \\
\text { (tku/(km/h)xkm) }\end{array}$ & [(tku generated)/(rail availability)] & Monthly \\
\hline & Terminals Utilization (\%) & [(carloads performed)/(Terminal Capacity]x100 & Monthly \\
\hline \multirow{4}{*}{$\begin{array}{l}\text { Maximize the } \\
\text { Availability and } \\
\text { Guarantee the } \\
\text { Reliability of Assets } \\
\text { In order to achieve } \\
\text { the excellence of } \\
\text { Maintenance } \\
\text { Management }\end{array}$} & Locomotive Availability (\%) & $\begin{array}{l}\sum_{l=1}^{N}[\text { Kgf.h available/ Total Kgf.h }] \times 100 / N \\
N=\text { Days accumulated on moth }\end{array}$ & Monthly/Daily \\
\hline & $\begin{array}{c}\text { Acomplishment of Projects } \\
\text { Deadlines for undercarriage } \\
\text { recovery }(\%)\end{array}$ & $\begin{array}{c}{[(\text { Project activities finished on time }) /(\text { Total of Projects }} \\
\text { Predicted })] \times 100\end{array}$ & Monthly \\
\hline & $\begin{array}{l}\text { Locomotive Reliability (Mean } \\
\text { Km betwwen failures) }(\mathrm{Km})\end{array}$ & $\begin{array}{l}\sum_{l=1}^{N}[\text { Km performed/ Total failures }] / N \\
N=\text { Days accumulated on month }\end{array}$ & Monthly/Daily \\
\hline & $\begin{array}{l}\text { Wagons Availability } \\
(\%)\end{array}$ & $\begin{array}{l}\sum_{l=1}^{N}[\text { Wagon.h available/ Total Wagons.h }] \times 100 / N \\
N=\text { Days accumulated on month }\end{array}$ & Monthly/Daily \\
\hline \multirow{2}{*}{$\begin{array}{l}\text { Maximize Rail } \\
\text { Availability and } \\
\text { Guarantee Project } \\
\text { Deliverables aiming } \\
\text { the excellence on } \\
\text { Rail Management }\end{array}$} & $\begin{array}{l}\text { Rail Availability } \\
(\mathrm{Km} / \mathrm{h}) \times \mathrm{Km}\end{array}$ & $\begin{array}{l}\sum_{i=1}^{N}\left[\sum_{i=1}^{n}(\text { Distance of strech } i) \times(\text { Veloc. strech }] I / N\right. \\
\begin{array}{l}N=\text { Days accumulated on month } \\
n=\text { number of streches }\end{array}\end{array}$ & Monthly/Daily \\
\hline & $\begin{array}{c}\text { Accomplishment of Projects } \\
\text { Deadline for Rail } \\
\text { Infrastructure and } \\
\text { Superstructure (\%) }\end{array}$ & {$[($ Project Finished on Time)/(Total or Projects Planned)]x100 } & Monthly \\
\hline
\end{tabular}


Continuation of Table 3

\begin{tabular}{|c|c|c|c|}
\hline \multirow{3}{*}{\begin{tabular}{|c|} 
Guarantee \\
Production \\
Exellence on \\
Transportation and \\
Handling Operations
\end{tabular}} & $\begin{array}{c}\text { Transportation Production } \\
\text { Efficiency }(\%)\end{array}$ & $\begin{array}{l}\left.\sum_{l=1}^{N}[(t k u \text { performed }) / d k u \text { planned })\right] \text { I x100/N } \\
N=\text { Days accumulated on month }\end{array}$ & Monthly/Daily \\
\hline & Load Efficiency $\quad$ (\%) & $\begin{array}{l}\sum_{l=1}^{N}[(\text { Wagons loaded }) /(\text { Wagons planned }] \mid \times 100 / N \\
N=\text { Days accumulated on month }\end{array}$ & Monthly/Daily \\
\hline & $\begin{array}{l}\text { Wagons Unload Efficiency } \\
(\%)\end{array}$ & $\begin{array}{l}\sum_{=1}^{N}[(\text { Wagons unloaded }) /(\text { Wagons planned })] \mid \times 100 / N \\
N=\text { Days accumulated on month }\end{array}$ & Monthly/Daily \\
\hline \multirow{4}{*}{$\begin{array}{c}\text { Guarantee and } \\
\text { Improve Terminal } \\
\text { Operations In order } \\
\text { to Achieve } \\
\text { Execellence on } \\
\text { Load and Unload } \\
\text { Operations }\end{array}$} & Terminals Availability (\%) & $\begin{array}{l}\sum_{l=1}^{N}[(\text { Total of hours available/ Total hours }] \text { I x100/N } \\
N=\text { Days accumulated on month }\end{array}$ & Monthly/Daily \\
\hline & $\begin{array}{l}\text { Wagons time in Terminal } \\
\text { (hours) }\end{array}$ & $\begin{array}{l}\sum_{l=1}^{N}\left[\sum(\text { Time of Permanence } i) / n\right] I / N \\
\mathrm{i}=1 \\
\mathrm{~N}=\text { Days accumulated on month } \\
\mathrm{n}=\text { number of Wagons }\end{array}$ & Monthly/Daily \\
\hline & Load Capacity Utilization (\%) &  & Monthly/Daily \\
\hline & $\begin{array}{l}\text { Time of Wait in Line of } \\
\text { Truchs for Transhipment } \\
\text { (hours) }\end{array}$ & $\begin{array}{l}\sum_{l=1}^{N}\left[\sum_{i=1}^{n}(\text { Full unload Time } i) / n\right] I / N \\
N=\text { Days accumulated on month } \\
n=\text { number of trucks }\end{array}$ & Monthly/Daily \\
\hline
\end{tabular}


Continuation of Table 3

\begin{tabular}{|c|c|c|c|}
\hline \multirow{3}{*}{$\begin{array}{c}\text { Guarantee } \\
\text { execellence on } \\
\text { Planning Activities }\end{array}$} & $\begin{array}{l}\text { Effectivenes Delivery to } \\
\text { Internal Customers } \quad(\%)\end{array}$ & [(Total of Demands Done $) /($ Total of Demands Planned)]x100 & Monthly \\
\hline & $\begin{array}{l}\text { Efficiency on New Service } \\
\text { Projects (\%) }\end{array}$ & {$[($ Projects Finished on time $) /($ Total of Projects Planned $)] \times 100$} & Monthly \\
\hline & $\begin{array}{c}\text { Accuracy on Production Plan } \\
(\%)\end{array}$ & $\begin{array}{c}{[(\text { tku performed }+ \text { losses tku not planned)/(total of tku }} \\
\text { planned })] \times 100\end{array}$ & Monthly \\
\hline \multirow{5}{*}{$\begin{array}{l}\text { Guarantee and } \\
\text { Improve Trains } \\
\text { Circulation In order } \\
\text { to achieve } \\
\text { excellence on } \\
\text { transportation } \\
\text { operations }\end{array}$} & Transit-Time of Trains (hours) & $\begin{array}{l}\sum_{l=1}^{N}\left[\sum_{i=1}^{n}(\text { Time between Origin and Destiny } \mathrm{i} / \mathrm{n}] \mathrm{I} / \mathrm{N}\right. \\
\mathrm{N}=\text { Days accumulated on month } \\
\mathrm{n}=\text { number of trains }\end{array}$ & Monthly/Daily \\
\hline & Wagons Cycle Time (hours) & $\begin{array}{l}\sum_{l=1}^{N}\left[\sum \text { (time between Origin and Destiny } \mathrm{i} / \mathrm{n}\right] \mathrm{I} / \mathrm{N} \\
\mathrm{N}=\text { Days acumulated on month } \\
\mathrm{n}=\text { number of wagons }\end{array}$ & Monthly/Daily \\
\hline & $\begin{array}{l}\text { Traction Capacity } \\
\text { Utilization(\%) }\end{array}$ & $\begin{array}{l}\sum_{l=1}^{N}\left[\sum_{i=1}^{n}(\text { tb pulled } / \text { tb of train-type }) i / n\right] I \times 100 / N \\
\begin{array}{l}N=\text { Days accumulated on month } \\
n=\text { number of trains }\end{array} \quad * \text { tb }=\text { gross tonne }\end{array}$ & Monthly/Daily \\
\hline & $\begin{array}{c}\text { Accident Index } \\
\text { ( Accident/million train.Km) }\end{array}$ & $\begin{array}{l}\text { (Accidents Ocurred) } /[(\text { Total of trains on month } \times \mathrm{Km} \\
\text { performed }) / 1,000.000]\end{array}$ & Monthly \\
\hline & Energetic Efficiency (l/tkb) & $\begin{array}{l}\text { (Total fuel consumed)/(tkb total pulled) } \\
{ }^{*} \mathrm{tkb}=\text { gross tonne } \mathrm{km}\end{array}$ & Monthly \\
\hline
\end{tabular}




\section{Conclusion and Final Remarks}

Railroad Transportation is the key for the more balanced transportation matrix in Brazil. Methods and theories can contribute to leverage the share of railroad transportation with regards total of goods to be moved. PMS has important role on the railroad performance management. However, literature review shows that most of PMS proposed are concentrated on operational, maintenance and sector aspects. Comprehensive, strategic and cause-and-effect PMSs are not considered by these proposals. This is against general theory of modern PMSs.

In order to try to fill this gap, this research aimed to present a PMS framework to be applicable at Railroad Companies. To elaborate this model, a case study was developed in a large Railroad Brazilian Company in order to understand the strategic objectives in terms of learning and growth, processes, customers and financial perspectives, This was necessary due to the choice of BSC structure as a basis for the PMS constructs.

It was possible to verify the suitability of BSC structure for the railroad companies. Also, evidences shows the real needs in have a strategic and broad perspective to properly measure railroad operations.

This research brings up significant for the PMS theory related to railways as study object once current PMSs proposed are not enough to effectively support the performance measurement needs from the Railroad companies' perspective. Also, it can be a reference guide for practitioners interested in implements effective PMSs into their organizations and in specific in Railroad Companies. From the Brazilian perspective, this PMS can help the improvement of Brazilian companies impacting on their performance management and consequently in a more balanced transportation matrix.

Future researches can be done in order to understand a little bit more aspects related to implementation and impacts with regards BSC adoption in Railways. Some research questions can be useful as reference for future studies as surveys, action researches and case studies as follows:

- What the impacts of BSC adoption in Railroads outcomes?

- What the barriers to implement BSC in Railroad Companies?

- Is the BSC effective to accomplish and support Railroad strategic objectives?

- How to effectively implement the BSC in Railways organizations?

\section{References}

Ahren, T., \& Aditya, P. (2009). Maintenance performance indicators (MPIs) for benchmarking the Railway infrastructure. Benchmarking: an international Journal, 16(2), 247-258. https://doi.org/10.1108/14635770910948240

Association of American Railroads. (2016). Railroads Drive American Economy. Retrieved from: https:// www.aar.org/Documents/SOTI\%20PDFs/AAR\%20State\%20of\%20the \%20Industry\%202016\%20Report\%2 02_C1A1.pdf

Association of Brazilian Railroad Companies. (2016). Mais Eficiência e Mais TKU. Brasília. Retrieved from: http://www2.antf.org.br/releases/mais-eficiencia-mais-tku/

Bititci, U. S., Carrie, A. S., \& McDevitt, L. (1997). Techniques integrated performance measurement systems: an audit and development guide. The TQM Magazine, 9(1), 46-53. https://doi.org/10.1108/09544789710159443

Bryman, A., \& Bell, E. (2007). Business Research Methods. Oxford: Oxford University Express, 2nd ed.

Eccles, R. G. (1991). Measuring Corporate Performance: The Performance Manifesto. Harvard Business Review, 69(1), 131-137.

Frost, B. (2000). Measuring Performance. Dallas: Measurement International.

Jorge-Moreno, J., \& Garcia-Gebrian, L. I. (1999). Measuring production efficiency in European Railways European Business Review, 99(5), 332-344.

Kaplan, R. S., \& Norton, D. P. (1996). The Balanced Scorecard: Translating Strategy into Action. Boston: Harvard Business Schoo Press.

Kaplan, R. S., \& Norton, D. P. (2001). Transforming the balanced scorecard from performance measurement to strategic management: Part II. Accouting Horizons, 15(2), 147-160. https://doi.org/10.2308/acch.2001.15.2.147

Lan, W. L., \& Lin, E. J. (2006). Performance measurement for Railway Transport: Stochastic distance functions 
with inefficiency and ineffectiveness effects. Journal of Transport Economics and Policy, 40(3), 383-408. Retrieved from: https://www.jstor.org/stable/20053992?seq=1\#page_scan_tab_contents

Lebas, M. J. (1995). Performance measurement and performance management. International Journal of Production Economics, 41, 23-35. https://doi.org/10.1016/0925-5273(95)00081-X

Ministry of Transportation. (2012). Plano Nacional de Logística e Transportes. Brasília. Retrieved from: http://bibspi.planejamento.gov.br/bitstream/handle/iditem/559/ arq1352743917.pdf?sequence=1

Ministry of Transportation. (2016). Transporte Ferroviário. Brasília. Retrieved from: http://www.transportes. gov.br /transporte-ferroviario-relevancia.html

Mir Ali, H. R., Ghaderi, H. R., \& Rostami, F. (2013). Review the Role of the Balanced Scorecard in the effectiveness of Office in Khorasan Railway. International Journal of Engineering Research and Applications, 3(5), 1315-1319. Retrieved from: http://www.ijera.com/papers/Vol3_issue5/HN3513151319.pdf

Neely, A., Adams, C., \& Crowe, P. (2001). The performance prism in practice. Measuring Business Excellence, 5(2), 6-13. https://doi.org/10.1108/13683040110385142

Neely, A., Gregory, M., \& Platts, K. (1995). 'Performance measurement system design. International Journal of Operations Management, 14(4), 81-114. https://doi.org/10.1108/01443579510083622

Niven, P. (2002). Balanced Scorecard step-by-step: Maximizing Performance and Maintaining Results, New York: John Wiley \& Sons.

Rajeev, R., Chatterjee, P., \& Chakraborty, S. (2016). Performance evaluation of Indian Railway Zones using DEMATEL and VIKOR methods. Benchmarking: an International Journal, 23(1), 78-95. https://doi.org/10.1108/BIJ-09-2014-0088

Sajeev, A. G., \& Narayan, R. (2008). A performance benchmarking study of Indian Railway Zones. Benchmarking: an International Journal, 15(5), 599-617. https://doi.org/10.1108/BIJ-09-2014-0088

Sharma, M. G., Debnath, R. M., Oloruntoba, R., \& Sharma, S. M. (2016). Benchmarking of rail transport service performance through DEA for Indian Railways. International Journal of Logistics Management, 27(3), 629-649. https://doi.org/10.1108/JLLM-08-2014-0122

Stenstrom, C., Parina, C., \& Galar, D. (2012). Performance indicators of railway infrastructure. Journal of Railway Technology, 1(3), 1-8. https://doi.org/10.4203/ijrt.1.3.1

Towson University. (2016). Regional Economic Studies Institute. Towson, Maryland. Retrieved from: https://www.aar.org/Documents/AAR\%20Towson\%20Freight\%20Rail\%20Economic\%20Report\%20June\% 202016.pdf

Van Aken, E., Lettens, G., Coleman, G., Farris, J., \& Van Goubergen, D. (2005). Assessing maturity and effectiveness of enterprise performance measurement systems. International Journal of Productivity and Performance Management, 54(6), 400-418. https://doi.org/10.1108/17410400510604557

Voepel, S. C., Leibold, M., \& Eckhoff, R. A. (2006). The tyranny of the Balanced Scorecard in the innovation economy. Journal of Intellectual Capital, 7(1), 43-60. https://doi.org/10.1108/14691930610639769

Voss, C., Tsikriktsis, N., \& Frohlich, M. (2002). Case Research in Operations Management. International Journal of Operations \& Production Management, 22(2), 195-219. https://doi.org/10.1108/01443570210414329

Walters, M. (1999). Performance Measurement Systems: a case study of customer satisfaction. Facilities, 17(3/4), 97-104. https://doi.org/10.1108/02632779910256371

Wettstein, T., \& Kueng, P. (2002). A Maturity Model for Performance Measurement Systems. Management Information Systems, 113-122. Retrieved from: https://www.witpress.com/Secure/elibrary/papers/MIS02/MIS02011FU.pdf

Yin, R. (2003). Case study research: design and methods, 3rd ed, Sage Publications, London.

\section{Copyrights}

Copyright for this article is retained by the author(s), with first publication rights granted to the journal.

This is an open-access article distributed under the terms and conditions of the Creative Commons Attribution license (http://creativecommons.org/licenses/by/4.0/). 